\title{
Transport miejski w koncepcji logistyki miasta a zrównoważony rozwój
}

\section{Katarzyna Huk \\ Uniwersytet Zielonogórski \\ E-mail: k.huk@wez.uz.zgora.pl ORCID: 0000-0002-4476-6062}

\section{Weronika Bednarek}

Uniwersytet Zielonogórski

E-mail:werbed@interia.pl ORCID: 0000-0002-8536-7076
Publikacja sfinansowana przez: Małopolska Wyższa Szkoła Ekonomiczna w Tarnowie

\section{Korespondencja:}

Katarzyna Huk

Uniwersytet Zielonogórski Instytut Nauk o Zarządzaniu i Jakości, ul. Podgórna 50, 65-001 Zielona Góra

E-mail:k.huk@wez.uz.zgora.pl
Agata Górak

\author{
Uniwersytet Zielonogórski \\ E-mail: agata_g615@wp.pl \\ ORCID: 0000-0002-5669-9442
}

Natalia Bajda

\author{
Uniwersytet Zielonogórski \\ E-mail: natalia-bajda@wp.pl \\ ORCID: 0000-0003-3269-656X
}

\begin{abstract}
Streszczenie: Odpowiednie zrównoważenie wszystkich czynników w gospodarce jest kluczowe do dalszego rozwoju, a także przyszłości społeczeństwa i warunków życia. Stąd istotne wydaje się odpowiednie gospodarowanie czynnikami, a także eksploatacją środowiska. Jednym z rozwiązań jest odpowiedzialne podejmowanie działań w zakresie logistyki miejskiej. Tylko odpowiednie zarządzanie w myśl zrównoważonego rozwoju może dać społeczeństwu dobre warunki życia w aglomeracji, a także dalszy rozwój gospodarce poprzez napływających inwestorów. W artykule podjęto tematykę zrównoważonego rozwoju w logistyce miejskiej w ujęciu przemieszczania ludzi. Celem artykułu jest analiza wykorzystania w aglomeracjach autobusów i aut osobowych pod kątem środka napędu (ekologiczne i tradycyjne formy transportu). Analiza została przeprowadzona w rozbiciu na poszczególne powiaty. Ograniczono ją do Polski, ze szczególnym uwzględnieniem województwa lubuskiego. Artykuł został oparty na analizie literatury przedmiotu oraz o danych statystycznych.
\end{abstract}

Słowa kluczowe: kkoncepcja logistyki miejskiej, zrównoważony rozwój, transport miejski, autobusy

\section{Wprowadzenie}

Determinantem poprawnego działania danego systemu jest wyznaczenie konkretnych celów i zadań do zrealizowania. Jako główny cel funkcjonowania aglomeracji należy obierać nieustanny rozwój. Każde miasto posiada swoją specyfikę zależną od położenia geograficznego, głównego celu działania, 
zasobów naturalnych itd. Stąd też konieczny jest nieustanny rozwój zapewniający rozszerzanie podstawowej działalności i atrybutów danej aglomeracji. Jednocześnie nie można przy tym zapominać o konieczności: zapewnienia oczekiwanego poziomu życia mieszkańców, rozsądnego zarządzania systemem miejskim oraz wdrażania procedur odpowiadających ochronie środowiska. Miasta to również możliwości rozwoju różnego rodzaju inwestycji, stąd biorąc pod uwagę dalszą ekspansję należy również uwzględniać możliwości przyciągnięcia potencjalnych inwestorów. Stąd też, w logistyce miejskiej dużą rolę pełnią interesariusze, z tymże nie tylko władze zarządzające miastem, ale także inne grupy społeczne, np. dostawcy infrastruktury, właściciele nieruchomości itd. (Browne, Lindholm, Allen, 2015, s. 19).

Wdrażane procedury oraz działania związane z logistyką miejską powinny być zgodne z zasadami zrównoważonego rozwoju. Wiąże się to z poszukiwaniem możliwych optymalnych rozwiązań, mogących wpłynąć na polepszenie jakości, efektywności i opłacalności wykonywanych usług, mając równocześnie na uwadze oddziaływanie na środowisko naturalne.

Celem artykułu jest prezentacja poziomu wykorzystania w aglomeracjach autobusów i aut osobowych pod kątem środka napędu (ekologiczne i tradycyjne formy transportu). Analiza została przeprowadzona w rozbiciu na poszczególne powiaty. Ograniczono ją do Polski, ze szczególnym uwzględnieniem województwa lubuskiego. Artykuł został oparty na analizie literatury przedmiotu oraz o danych statystycznych.

\section{Zrównoważony rozwój a logistyka miasta}

Pojęcie zrównoważonego rozwoju obecnie jest kwestią poruszaną w większości procesów decyzyjnych, podejmowanych przez władze działające na szczeblach regionalnych, krajowych, europejskich czy międzynarodowych (Russo i in., 2020, s. 619-629). Według Sakhapowa i Nikolaevej (2021) działania zmierzające do zrównoważenia transportu odnoszą się do realizacji procesów w taki sposób, aby „zaspokoić obecne potrzeby transportowe ludzkości, nie pozbawiając przyszłych pokoleń możliwości zaspokojenia ich potrzeb transportowych" (Sakhapowa, Nikolaeva, 2021). Priorytetem każdej jednostki terytorialnej powinno być działanie służące nie tylko rozwojowi zrównoważonemu, ale również trwałemu, który będzie akceptowany przez społeczeństwo, bezpieczny dla ekologii oraz o charakterze realnym ekonomicznie (Witkowski, Stajniak, Chojnacka, 2016, s. 451). Zrównoważony rozwój to wpływ na społeczeństwo i otoczenie (Bajdor, Pawełoszek, Fidlerova, 2021, s. 2). Stanowi on odpowiedź na trzy główne problemy współczesnego świata: rozwój gospodarczy, postęp społeczny i relacje ze środowiskiem (Gore, 1992; Norouzi, Ataei, s. 69; Surówka i in., 2021, s. 1). Należy również zwrócić uwagę, iż „zrównoważony rozwój opiera się na integracji gospodarczo-środowiskowej, ochronie środowiska, zaangażowaniu międzypokoleniowym oraz sprawiedliwości międzypokoleniowej i jakości życia oraz udziale jednostek w procesie rozwoju. Staje się konkretny, gdy poprawia jakość ludzkiego życia, a po drugie, żywotność planety" (Norouzi, Ataei, s. 69; Kelimeler, 2020, s. 1923). Zrównoważony rozwój omawia kwestie nie tylko teraźniejszości, ale również konieczności zadbania o potrzeby przyszłych pokoleń (WCED, 1987, s. 300). Jednym z największych zagrożeń jest wpływ zarówno w odniesieniu do gospodarstw domowych, jak również całego przemysłu - energii, zużycia wody, wpływu na środowisko naturalne, zużywania się surowców naturalnych 
itd. (Fidlerová, Míkva, 2018, s. 90; Straka, Rosova, 2018, s. 1; Olajuyin i in., 2019, s. 12-15; Japee, Oza, 2021, s. 5610-5619; Brent, 2021, s. 1). Tak więc zrównoważony rozwój dotyczy całego świata, a także w mniejszej skali poszczególnych obywateli. Jednym z obszarów jej zainteresowania są miasta, które jako mniejsze, bądź większe skupiska ludności i organizacji, oddziałują na środowisko, ekonomię i społeczeństwo. Istotne jest więc odniesienie zrównoważonego rozwoju do istoty zarządzania miastem, a tym samym koncepcji logistyki miasta.

W ostatnim okresie powstała nowa koncepcja logistyki miasta, której jednym z kluczowych aspektów jest dbanie o zrównoważony rozwój. Logistyka miasta według de Luca (2010) jest obszarem, który obejmuje m.in. optymalizację transportu ładunku i osób w granicach miast. Jednym z celów logistyki miejskiej są działania zmierzające do osiągnięcia balansu pomiędzy potrzebą zwiększenia wydajności transportu a negatywnym wpływem tych procesów na ekosystem (Tadić, Zečević, Krstić, 2015). M. Szymczak (2008) określił pięć obszarów logistyki miejskiej, obejmujących: „towarowy transport w mieście, transport dostawczy i wywozowy, a także przewozy tranzytowe, zabezpieczenie i składowanie dóbr na rzecz miasta, osobowy transport miejski i podmiejski oraz osobowy ruch tranzytowy, zaopatrzenie miasta, wywóz z miasta odpadów i odprowadzanie nieczystości" (Szymczak, 2008). Zwraca on szczególną uwagę na transport i przemieszczanie ładunków, osób, a także odpadów odbywających się na obszarze miasta, a także dotyczący połączeń z innymi aglomeracjami i makroregionami. Tak więc jednym z kluczowych zadań logistyki miasta jest tworzenie miejskiego systemu transportowego, którego celem będzie optymalizacja czasu przemieszczania się (Ehmke, 2012). Ponadto Taniguchi (2014) zwraca uwagę na dodatkowe wyzwania, które stoją przed logistyką miejską, takie jak: minimalizowanie zjawiska kongestii transportowej oraz racjonalne gospodarowanie energią. Logistykę miasta można bezpośrednio odnieść również do społecznej odpowiedzialności biznesu, których jeden ze wspólnych i kluczowych aspektów będzie środowiskowy (Huk, 2015; Huk, Witkowski, Wasilewski, 2016; Huk, Szudra, 2016).

Zarządzanie miastem wymaga ciągłej poprawy jakości realizowanych procesów. Oprócz aspektu ekologicznego istotny jest również aspekt ekonomiczny. Zrównoważony rozwój w tym obszarze sprowadza się do redukcji kosztów związanych z działaniami związanymi z logistyczną obsługą miasta. Jako cel społeczny natomiast logistyka miasta stawia sobie postępowanie w taki sposób, aby w jak najlepszy sposób zaspokajać potrzeby mieszkańców. Sposobem na osiągnięcie sukcesu jest zrównoważenie działań we wszystkich trzech wymienionych obszarach, tj. ekologicznym, ekonomicznym i społecznym (Saniuk, Witkowski, 2011). Ponadto aglomeracje dysponują instrumentami, które również można uznać za czynniki zrównoważonego rozwoju gminy oraz miasta. Zaliczamy do nich: strategie rozwoju, budżet, studium uwarunkowań i warunków zagospodarowania przestrzennego, miejscowy plan zagospodarowania przestrzennego (Sekuła, 2002, s. 331). Zrównoważony rozwój będzie więc odpowiadał za zachowanie odpowiednich proporcji pomiędzy wymienionymi obszarami, a jego wpływ w logistyce miejskiej w największym stopniu będziemy identyfikować w obszarze transportu i przemieszczania osób, materiałów, ładunków itd. 


\section{Transport miejski a zrównoważony rozwój - analiza wykorzystania środków transportu miejskiego w Polsce}

Transport publiczny odgrywa niebagatelną rolę w życiu mieszkańców miast. Zadowalający dostęp do środków transportu publicznego jest jednym z determinantów decydujących o atrakcyjności danego regionu. Transport miejski powinien być zgodny z zasadami zrównoważonej mobilności, a przy tym musi spełniać wymogi dotyczące bezpieczeństwa oraz dostępności dla użytkowników (Brzustewicz, 2013). W transporcie miejskim przez użytkowników wykorzystywane są następujące pojazdy: samochody osobowe, autobusy, tramwaje, metro, rower miejski, hulajnogi, skutery miejskie, trolejbusy. Na potrzeby lepszego zobrazowania dynamiki wykorzystania pojazdów w poszczególnych województwach w Polsce, na poniższym wykresie przedstawiono liczbę ludności Polski w 2019 r. z podziałem na województwa (rysunek 1). Niestety z uwagi na brak aktualnych danych w międzynarodowych bazach za okres analizy przyjęto lata 2015-2019.

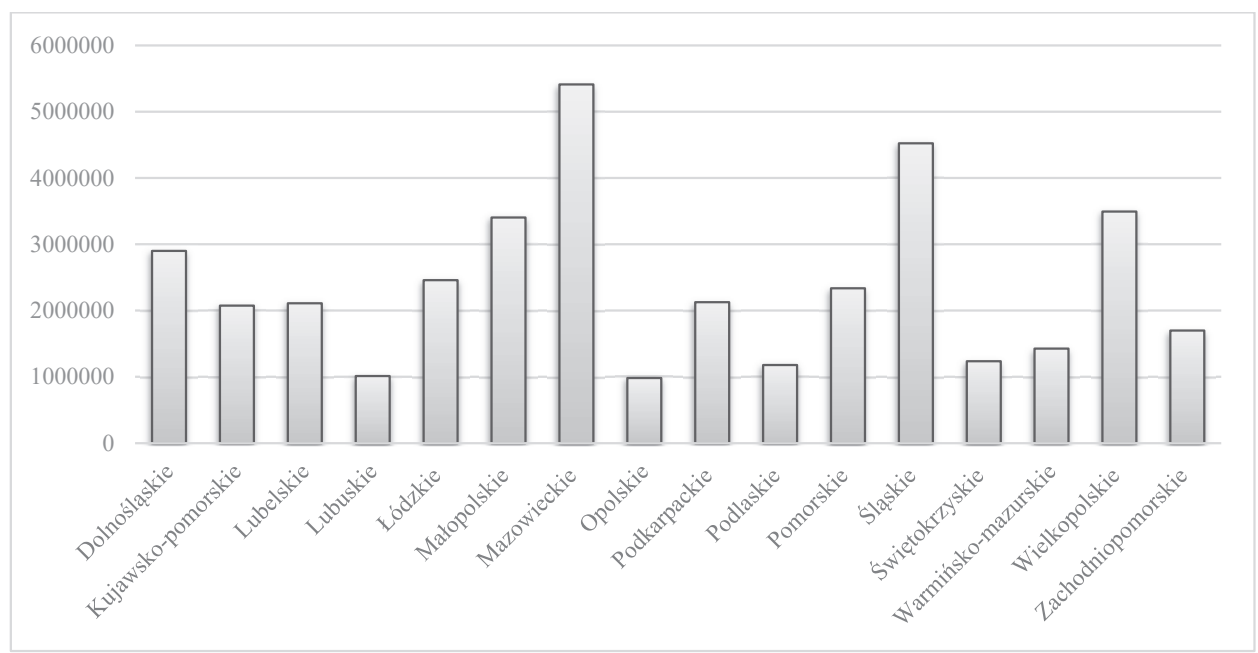

Rysunek 1. Ludność w Polsce w 2019 - podział na województwa

Źr ódło: opracowanie własne na podstawie: GUS, 2021; BZ, 2021.

Polska dzieli się na 16 województw. W 2019 r. najwięcej Polaków zamieszkiwało w województwie mazowieckim (ponad $5 \mathrm{mln}$ osób). W województwie tym znajduje się miasto stołeczne Warszawa, które liczy ponad 3 mln mieszkańców. Ponad 400 tys. Polaków zamieszkuje województwo śląskie, które dodatkowo charakteryzuje się dużą gęstością zaludnienia. Najmniejsza liczba ludności zamieszkuje w województwach: lubuskim i opolskim (około 1 mln mieszkańców w każdym).

Niezależnie od liczby ludności, w każdym wyróżnionym obszarze mieszkańcy przemieszczają się, wykorzystując różnorakie pojazdy. Podczas codziennych podróży korzystają m.in. z autobusów lub własnych samochodów osobowych, napędzanych różnymi paliwami, np. benzyną czy olejem napędowym. Dla każdego województwa przedstawiono liczbę zareje- 
strowanych autobusów i samochodów osobowych w latach 2015-2019, spalających benzynę, olej napędowy, gaz oraz liczbę pojazdów klasyfikowanych jako „,pozostałe”, czyli pojazdów hybrydowych, z zasilaniem elektrycznym lub innym alternatywnym źródłem energii. Obliczono również wskaźnik przedstawiający ilość pojazdów zarejestrowanych w danym województwie przypadającą na jednego mieszkańca w 2019 r. według poniższego wzoru:

$$
\text { LZPNMW }=\frac{\text { liczba zarejestrowanych pojazdów } w \text { danym województwie }}{\text { liczba mieszkańców danego województwa }}
$$

gdzie:

LZPNMW - liczba zarejestrowanych pojazdów przypadająca na jednego mieszkańca województwa.

Odnosząc dane o zaludnieniu danych województw porównano je z danymi o ilości autobusów (rysunek 2) oraz aut osobowych (rysunek 3) zarejestrowanych w danych obszarach.

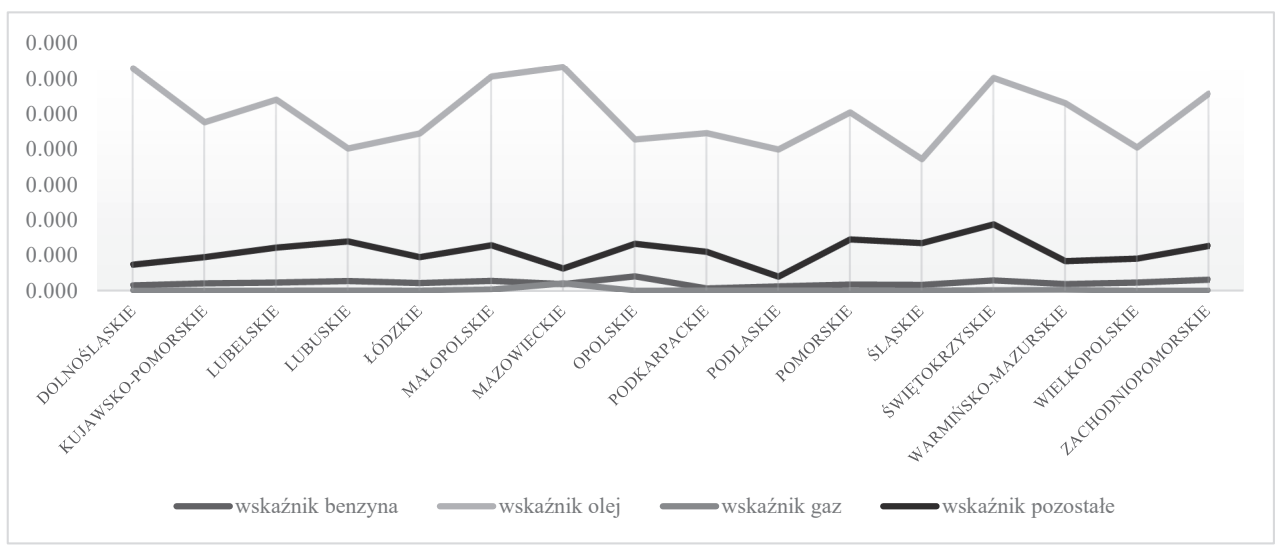

Rysunek 2. Liczba zarejestrowanych autobusów przypadająca na jednego mieszkańca województwa

Źr ódło: opracowanie własne na podstawie: GUS, 2021; BZ, 2021.

Z przeprowadzonej analizy wykorzystania autobusów z uwzględnieniem środka napędu i zaludnienia danego województwa wynika:

- najwyższą wartość wskaźnika liczby autobusów spalających olej napędowy osiągnięto dla województwa mazowieckiego, natomiast najniższą wartość odnotowano dla województwa śląskiego,

- najwyższą wartość wskaźnika w przypadku paliw alternatywnych odnotowano dla województwa świętokrzyskiego, najsłabiej zaś wypada województwo podlaskie oraz mazowieckie,

- w Polsce zdecydowanie dominuje wykorzystanie autobusów napędzanych olejem napędowym. Warto zauważyć, iż w województwie mazowieckim, jako największym w Polsce, dominują środki transportu miejskiego z wykorzystaniem oleju napędowego, natomiast najmniej środków transportu jest na alternatywne formy (autobusy elektryczne itd.). 
- województwo wielkopolskie natomiast minimalizuje autobusy na olej napędowy, a inwestuje właśnie w alternatywne, prośrodowiskowe formy transportu.

Podobnej analizy dokonano w stosunku do aut osobowych. Na poniższym rysunku (rysunek 3) przedstawione zostały auta osobowe zarejestrowane w Polsce z uwzględnieniem formy napędu.

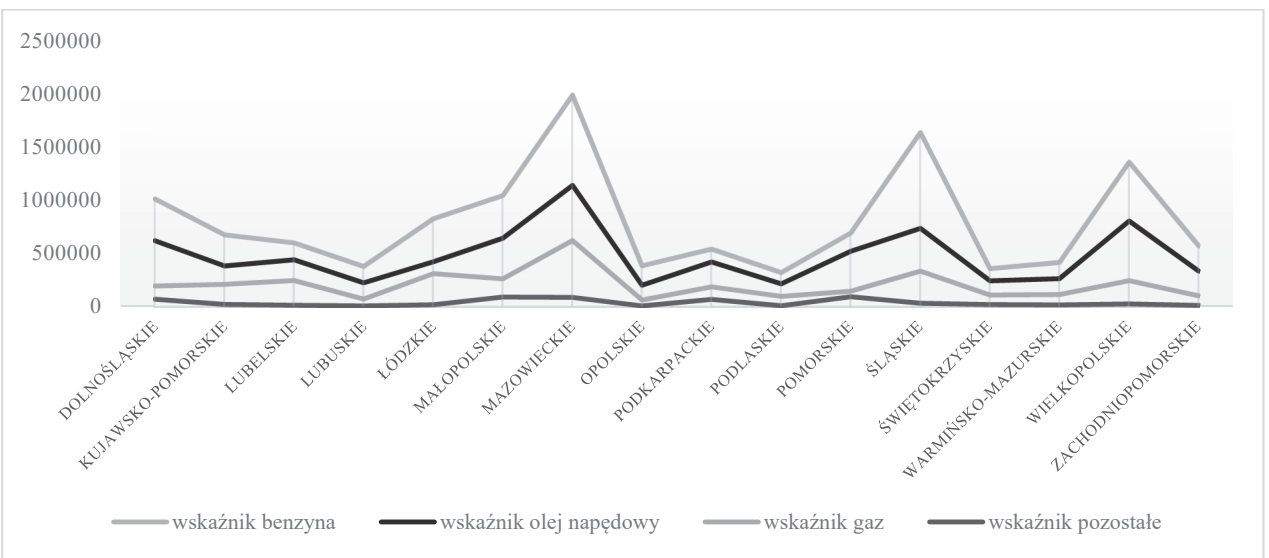

Rysunek 3. Liczba zarejestrowanych aut osobowych przypadająca na jednego mieszkańca województwa

Źr ódło: opracowanie własne na podstawie: GUS, 2021.

Przeprowadzona analiza wskazuje na wykorzystanie aut osobowych na jednego mieszkańca z podziałem na poszczególne województwa. Z przeprowadzonej analizy wynika:

- w województwie mazowieckim, śląskim i wielkopolskim jest najwyższy wskaźnik aut przypadających na jednego mieszkańca, co wskazuje, iż w większych miastach pomimo wielu rozwiązań dotyczących alternatywnych form transportu mieszkańcy kupują najwięcej aut na gospodarstwo domowe,

- wśród aut decydują te wykorzystujące benzynę, olej napędowy, a następnie gaz i formy alternatywne (np. auta elektryczne),

- pomimo wielu nowych rozwiązań, świadomości społeczeństwa o prośrodowiskowych formach transportu osobowego, polityce i kampanii prośrodowiskowych, np. aut elektrycznych, wskaźnik ten jest na dość niskim poziomie,

- nie ma zależności pomiędzy kupnem aut elektrycznych a wielkością województwa, stąd można też stwierdzić, iż dochody mieszkańców w większych miastach mają mniejszy wpływ na zakup tego rodzaju pojazdów. 


\subsection{Liczba autobusów w Polsce z podziałem na stosowany rodzaj napędu}

Aspekt środowiskowy w logistyce miejskiej to przede wszystkim środki transportu miejskiego. Stąd też analizie poddane zostały dane dotyczące wykorzystania autobusów z podziałem na rodzaj paliwa, w podziale na województwa oraz w ujęciu lat 2015- 2019, co przedstawia rysunek 4.

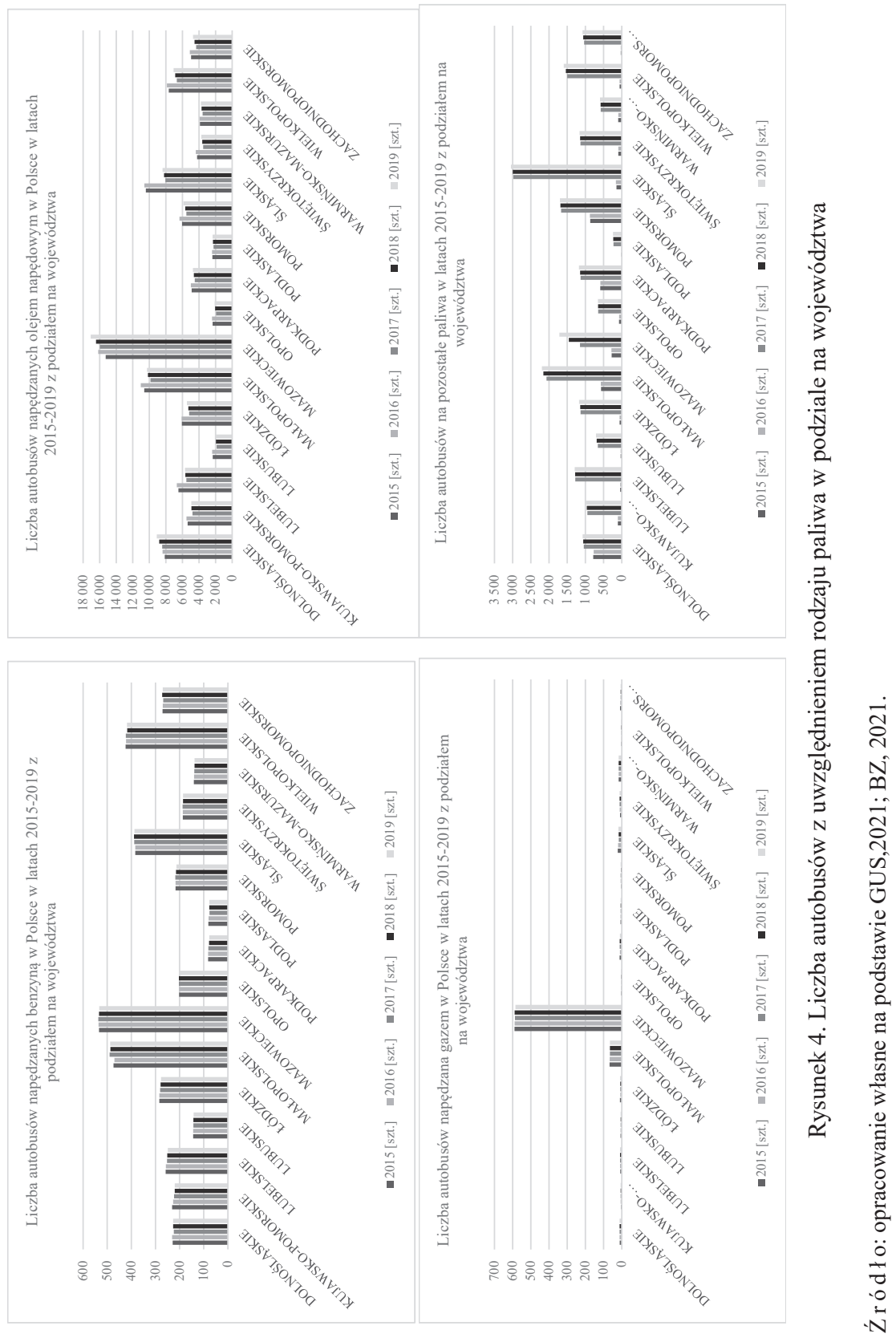


W okresie 2015- 2019 widać dużą tendencję zmian liczby autobusów (rysunek 4). Zmiany te są w głównej mierze wynikiem wprowadzanych wytycznych odnośnie do transportu miejskiego oraz możliwości inwestycji w nowy tabor. Z przeprowadzonej analizy można wyciągnąć następujące wnioski:

- niezmiennie od 2015 r. największa liczba autobusów spalających benzynę zarejestrowana jest w województwie mazowieckim. Najmniej takich autobusów zarejestrowano w województwach: podkarpackim i podlaskim;

- największą popularnością w Polsce pod względem pojazdów zbiorowych z gałęzi transportu drogowego cieszą się autobusy napędzane olejem napędowym. Najwięcej autobusów napędzanych olejem napędowym zarejestrowano, podobnie jak w przypadku pojazdów na benzynę, w województwie mazowieckim. Najmniej autobusów na olej napędowy jest zarejestrowane w województwach: lubuskim, opolskim i podlaskim;

- we wszystkich województwach odnotowano spadek pojazdów transportu zbiorowego napędzanych olejem napędowym w 2017 r. w porównaniu do roku 2016, gdzie największe zmniejszenie ilości odnotowano w województwie śląskim;

- Biała Księga Transportu z 2011 r. opracowana przez Komisję Europejską przewiduje ograniczenie gazów cieplarnianych do 2030 r. o 20\% w porównaniu z rokiem 2008 oraz do $2030 \mathrm{r}$. ograniczenie o połowę liczby pojazdów z silnikami spalinowymi i ich całkowitą eliminację z miast do 2050 r. (Komisja Europejska, 2011);

- autobusy spalające gaz są najmniej popularnym rodzajem pojazdów tego typu w Polsce;

- w Polsce pod względem rejestracji pojazdów autobusowych na gaz zdecydowanie prowadzi województwo mazowieckie. Może to być spowodowane tym, iż w województwie mazowieckiem znajduje się Warszawa, która jest dużą aglomeracją, a autobusy spalające gaz są stosunkowo najtańsze w utrzymaniu. W 2019 r. najmniej autobusów na gaz zarejestrowano w województwach: wielkopolskim i opolskim;

- w każdym województwie w 2017 r. nastąpił znaczny wzrost liczby zarejestrowanych autobusów zasilanych alternatywnie. Dodatkowo, w każdym z województw można zauważyć tendencję wzrostową, analizując lata 2015-2019. Największa liczba autobusów zasilanych alternatywnie zarejestrowana jest w województwie śląskim, natomiast najmniej w województwie podlaskim. Może to być spowodowane faktem, że zakup autobusu elektrycznego wiąże się z kosztowną inwestycją, nie tylko w pojazdy, lecz także $\mathrm{w}$ infrastrukturę do ich ładowania;

- artykuł 68 wprowadzonej w 2018 r. Ustawy o elektromobilności i paliwach alternatywnych zakłada, że od dnia 1 stycznia 2022 r. udział pojazdów elektrycznych w całym taborze transportu publicznego będzie wynosić $10 \%$, natomiast od dnia 1 stycznia $2023 \mathrm{r}$. będzie to udział co najmniej $20 \%$. Dodatkowo artykuł ten przewiduje udział autobusów zeroemisyjnych (elektrycznych i napędzanych wodorem) w całości floty transportowej na poziomie $5 \%$ od 1 stycznia 2021 r. do 20\% od 1 stycznia 2025 r. (Ustawa z 11 stycznia 2018 r.);

- normy emisji spalin dla silników wysokoprężnych są regulowane przez Rozporządzenie Komisji UE z 2012 r. Aktualnie normą spalin ww. typów pojazdów jest norma EURO 6 ustalona w 2014 r. z późniejszymi zmianami w latach 2018-2019 (Rozporządzenie Komisji UE z 29 maja 2012 r.). 


\subsection{Liczba samochodów osobowych w Polsce z podziałem na stosowany rodzaj napędu}

Analogicznie do przeprowadzonej powyżej analizy zostaną przedstawione statystyki dotyczące liczby samochodów osobowych w Polsce w latach 2015-2019, co przedstawiają schematy poniżej (rysunek 5).
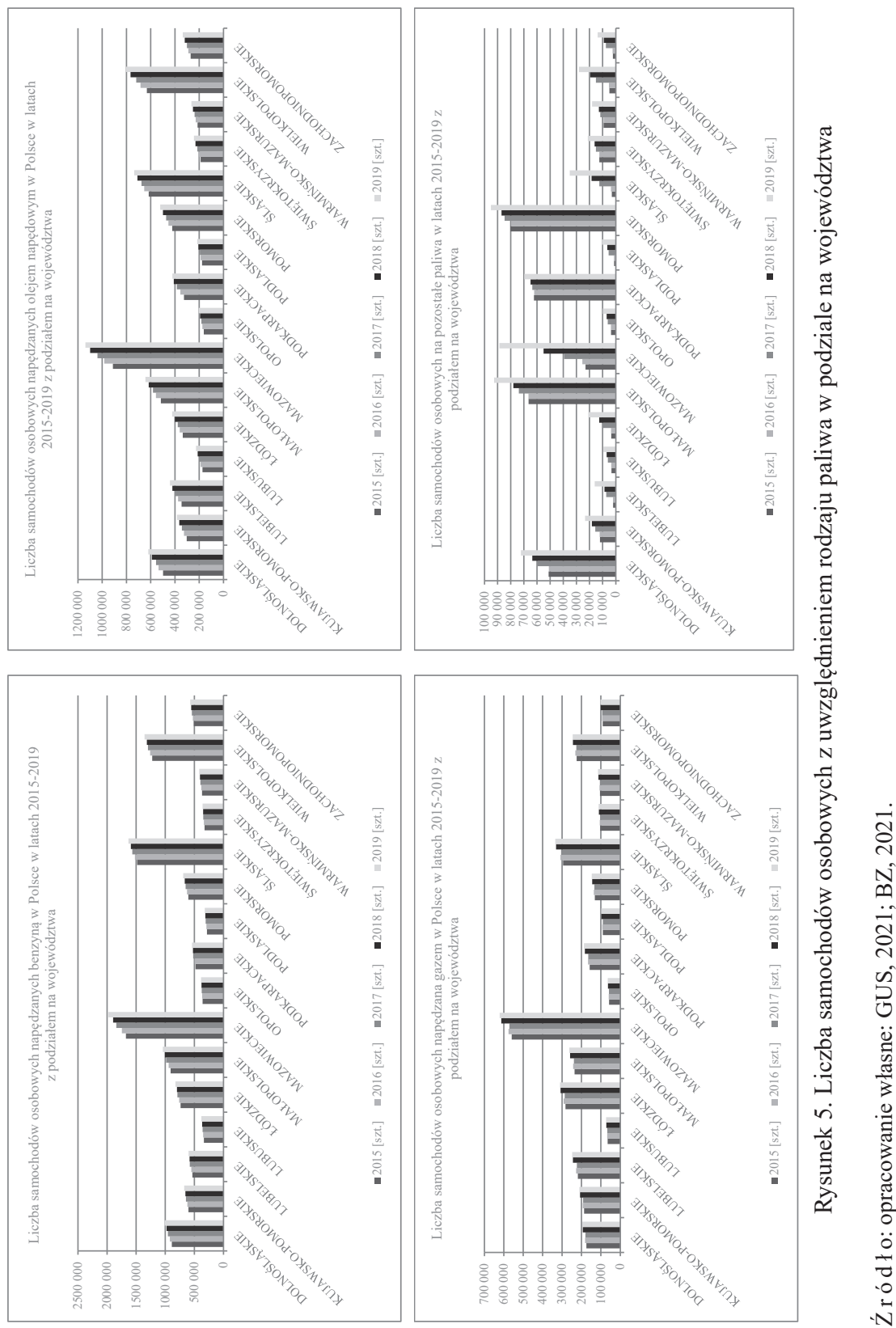
Ukazane na schematach (rysunek 5) dane statystyczne przedstawiają liczbę aut w zależności od roku, województwa, a także formy napędu aut osobowych. Uwzględnione zostały auta napędzane na benzynę, olej napędowy, gaz i inne formy, np. auta elektryczne. Należy zauważyć, iż wykresy te przedstawiają równe wielkości aut, dlatego należy zwrócić uwagę na oś wielkości. Z przedstawionych danych wynika, iż:

- wśród wszystkich województw w Polsce najmniejszą ilość samochodów napędzanych benzyną rejestruje się w województwie podlaskim. Najwięcej tego rodzaju samochodów jest w województwie mazowieckim;

- w każdym z województw w latach 2015- 2019 można zauważyć wzrost ilości samochodów napędzanych olejem napędowym. Najwięcej tego rodzaju pojazdów w roku 2019 odnotowano w województwie mazowieckim, a najmniej w województwie opolskim;

- Ministerstwo Klimatu i Środowiska planuje wprowadzić pewne zmiany w Ustawie o elektromobilności i paliwach alternatywnych. Przewiduje się zaktualizowanie dotychczasowych zaleceń co do stref czystego transportu w miastach. Będą one obowiązkowe w aglomeracjach liczących ponad 100 tys. mieszkańców, w których odnotowuje się niepokojący poziom wskaźnika zanieczyszczeń powietrza dwutlenkiem azotu $\left(\mathrm{NO}_{2}\right)(\mathrm{Gov} . p l, 2021)$;

- do strefy czystego transportu w mieście mogą wjchać pojazdy: elektryczne, zasilane wodorem, CNG oraz autobusy zeroemisyjne;

- największą ilość samochodów osobowych napędzanych gazem zanotowano w województwie mazowieckim. Najmniej samochodów przypisuje się województwu opolskiemu. Popularność tego typu pojazdów może wynikać z faktu, że cena za litr paliwa gazowego jest prawie dwa razy niższa od ceny jednego litra ropy i benzyny;

- na przestrzeni analizowanych lat 2015-2019 zauważalny jest istotny wzrost zarejestrowanych samochodów napędzanych pozostałym rodzajem paliwa. W roku 2019 najmniej tego rodzaju samochodów odnotowano w województwie lubuskim, a najwięcej w województwie pomorskim. Zakup samochodu osobowego o napędzie elektrycznym wiąże się z ogromnymi kosztami, co sprawia, że nie każdy uczestnik ruchu drogowego jest w stanie pozwolić sobie na taką inwestycję.

Polityka prośrodowiskowa zakłada wprowadzenie alternatywnych form energii, w tym wdrożenie pojazdów o alternatywnych środkach napędu. Z przeprowadzonej analizy wynika, iż występuje tendencja rosnąca w zakresie wykorzystania alternatywnych form napędu aut osobowych, a tendencja ta będzie się utrzymywać w przeciągu najbliższych lat. Do tego jednak niezbędne są dodatkowe formy zachęt stosowanych przez państwo, które zrekompensują wysokie koszty tychże aut.

\section{Transport miejski w koncepcji logistyki miasta na przykładzie województwa lubuskiego}

Województwo lubuskie zamieszkuje nieco ponad 1 mln mieszkańców, co sprawia, że jest to jedno z najmniej zaludnionych województw w Polsce. Znajduje się w zachodniej części Polski i graniczy z województwami: dolnośląskim, wielkopolskim i zachodniopomorskim oraz od zachodu z Niemcami. Posiada dwie główne miejscowości, które walczą o miano stolicy województwa Zieloną Górę oraz Gorzów Wielkopolski. 


\subsection{Transport miejski a powiaty województwa lubuskiego}

Województwo lubuskie dzieli się na 14 powiatów, z czego dwa to miasta na prawach powiatu, tj. Gorzów Wielkopolski i Zielona Góra. Dla każdego z powiatów zostanie policzony ten sam wskaźnik, który przypisywano dla wartości ogólnopolskich. Na poniższym wykresie (rysunek 6) przedstawiono liczebność poszczególnych powiatów województwa lubuskiego.

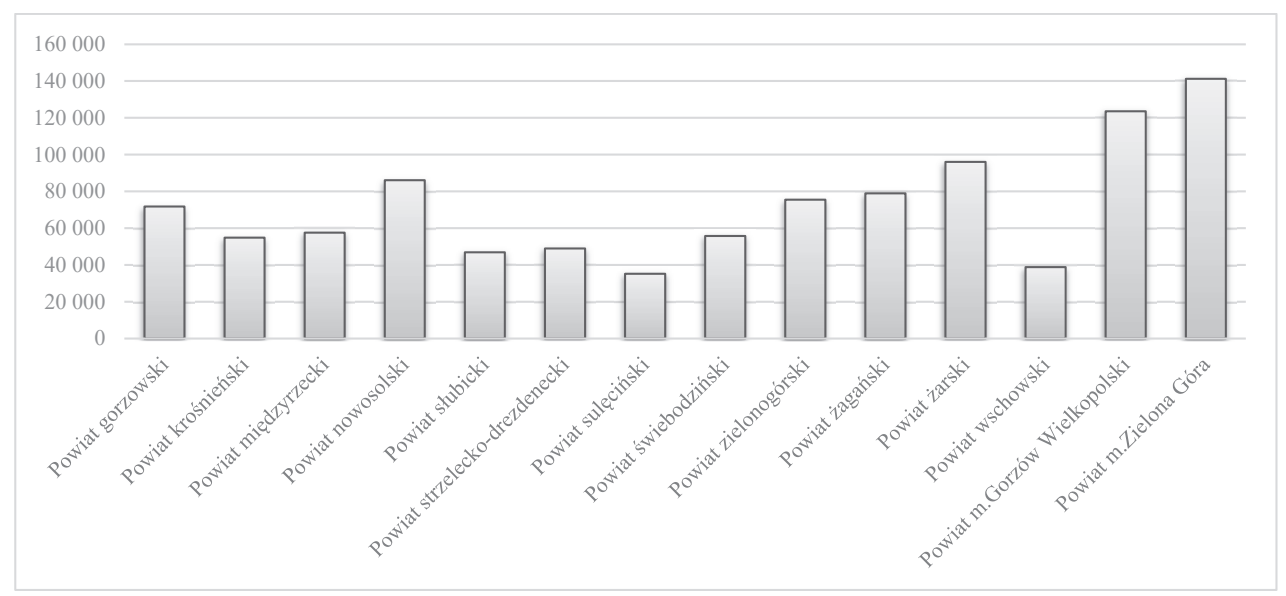

Rysunek 6. Ludność województwa lubuskiego w 2019 r. z podziałem na powiaty

Źr ódło: opracowanie własne na podstawie: GUS, 2021; Polska w liczbach, 2021.

Na poniższych wykresach (rysunek 7 i 8) zostały przedstawione wyniki uzyskane przy użyciu wzoru (1) dla liczby autobusów i samochodów osobowych przypadających na mieszkańca poszczególnego powiatu w województwie lubuskim.

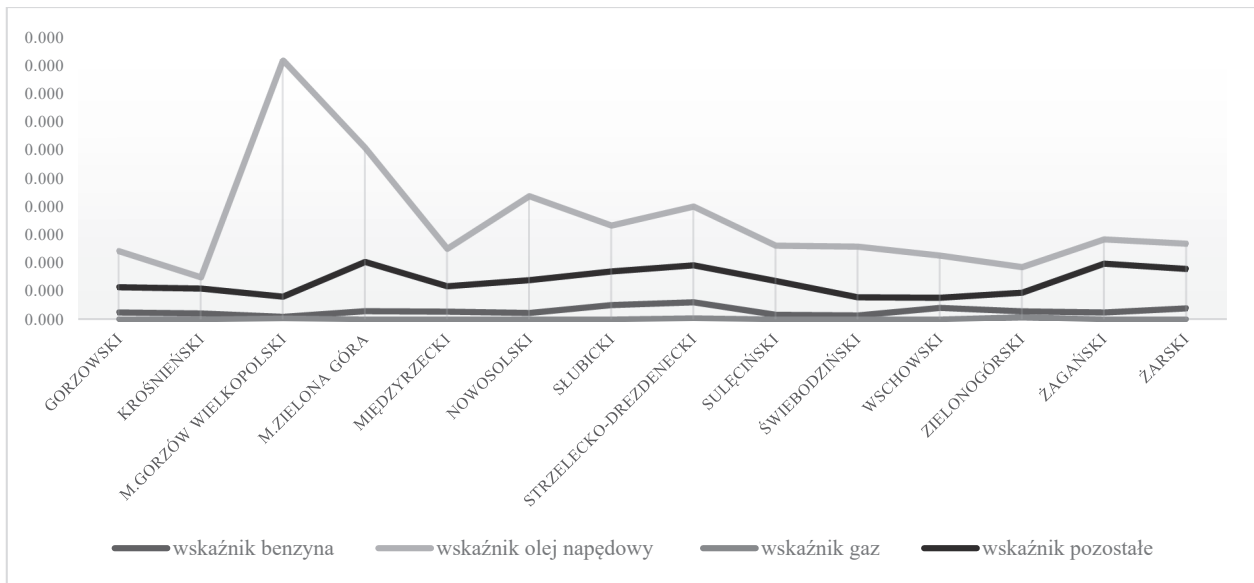

Rysunek 7. Liczba zarejestrowanych autobusów przypadająca na jednego mieszkańca powiatu w województwie lubuskim

Źr ód ło: opracowanie własne na podstawie: Polska w liczbach, 2021. 
Analizując wskaźnik liczby zarejestrowanych autobusów na jednego mieszkańca poszczególnych powiatów w województwie lubuskim dla roku 2019 można wywnioskować, iż:

- największa liczba autobusów przypadająca na jednego mieszkańca jest w miastach Gorzów Wielkopolski oraz Zielona Góra, a także w dalszej kolejności w powiatach nowosolskim i strzelecko-drezdeneckim,

- największy wskaźnik dla pozostałych rodzajów paliw odnotowano w powiecie miasto Zielona Góra, a najmniejszy w powiecie wschowskim,

- należy zauważyć, iż w kolejnych latach miasta inwestowały bardzo mocno w autobusy elektryczne, czego przykładem jest miasto Zielona Góra. Obecnie w roku 2021 prawie wszystkie autobusy zostały wymienione na elektryczne.

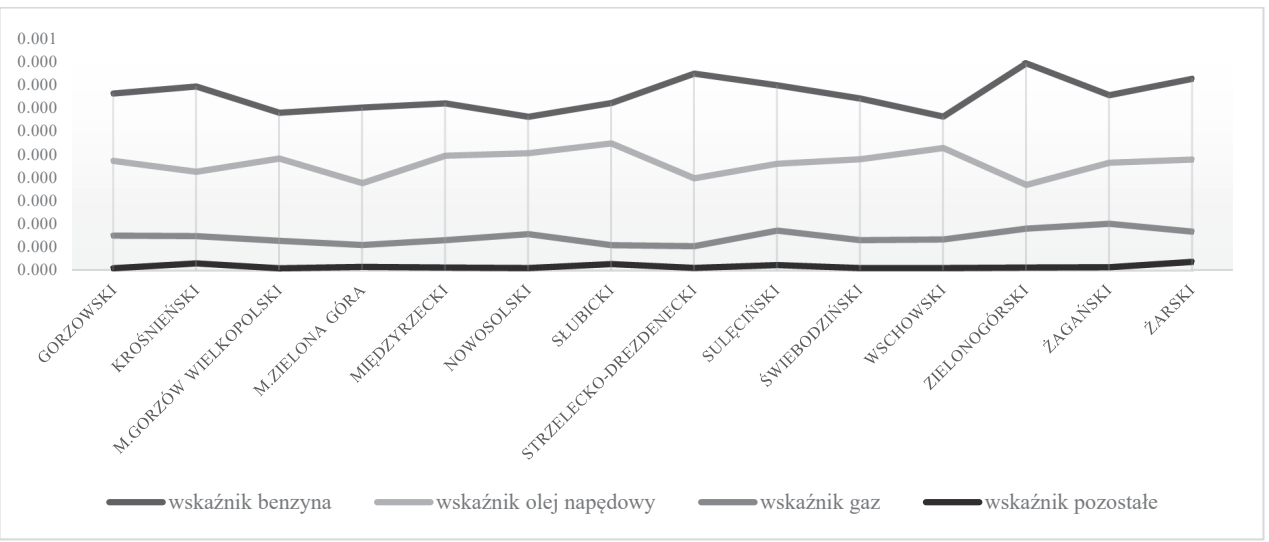

Rysunek 8. Liczba zarejestrowanych samochodów osobowych przypadająca na jednego mieszkańca powiatu w województwie lubuskim

Źr ódło: opracowanie własne na podstawie: Polska w liczbach, 2021.

W odniesieniu do aut osobowych wskaźnik liczby zarejestrowanych samochodów przypadających na jednego mieszkańca powiatu w województwie lubuskim jest podobny, jak w całej Polsce. Nie ma tutaj żadnej specyfiki, która świadczyłaby o charakterystycznych dla tego obszaru tendencjach. W tychże obszarach występuje podobny poziom poszczególnych aut osobowych dla analizowanych obszarów.

\subsubsection{Liczba autobusów w województwie lubuskim z podziałem na stosowany rodzaj napędu}

Poniżej zostaną przedstawione dane związane z rodzajem stosowanego napędu w autobusach w województwie lubuskim w latach 2015-2019 (rysunek 9). 

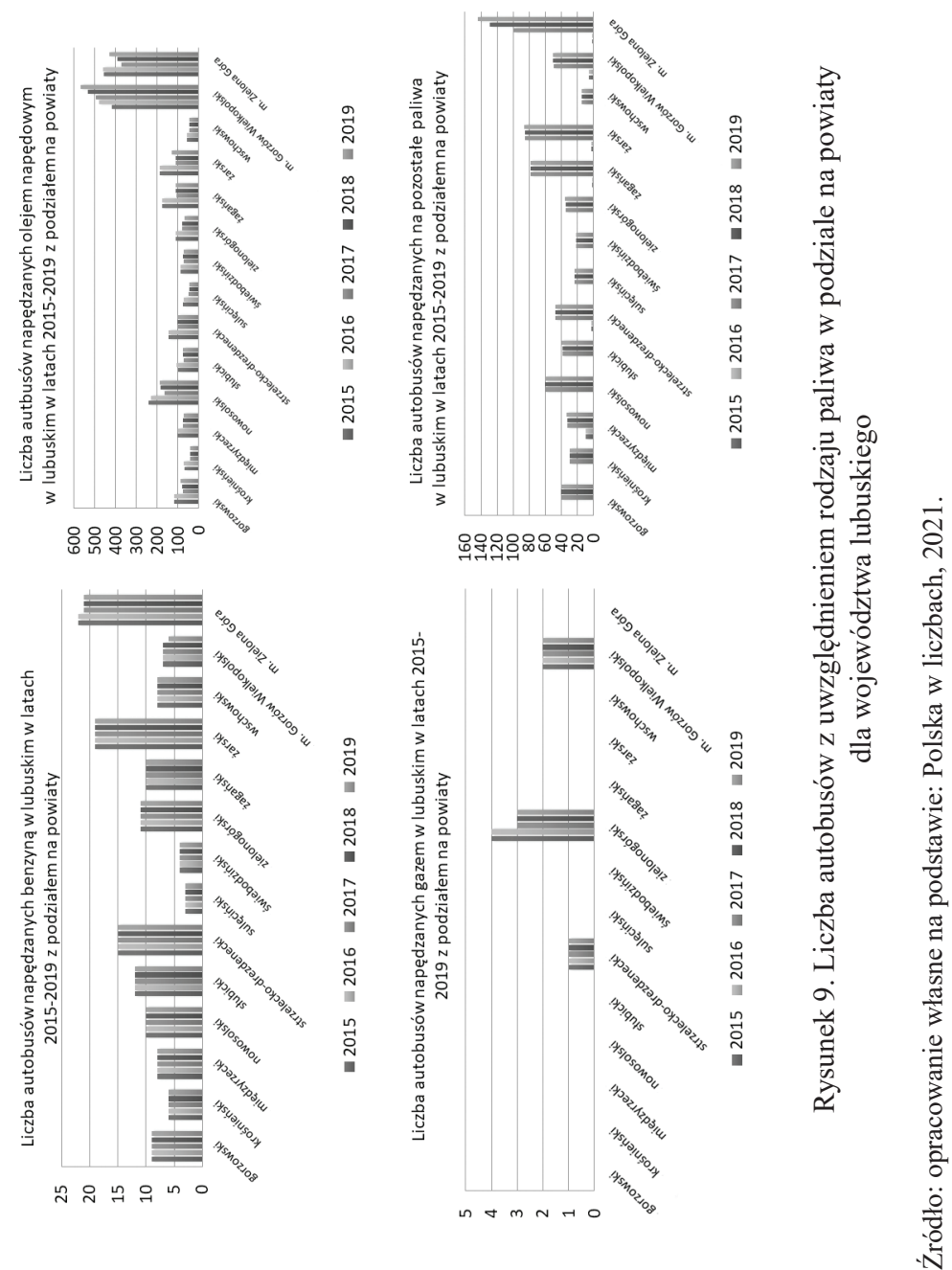
Przedstawione dane (rysunek 9) wskazują na podobne tendencje, jak w całej Polsce. Liczba autobusów jest zależna od wielkości miasta oraz stosowanej polityki w zakresie logistyki miasta. Można wywnioskować, iż:

- największą ilość zarejestrowanych autobusów o napędzie benzynowym odnotowano w mieście Zielona Góra, a najmniej w powiecie sulęcińskim;

- najwięcej zarejestrowanych autobusów spalających olej napędowy jest w Gorzowie Wielkopolskim. Najmniej zarejestrowanych tego typu pojazdów jest w powiecie wschowskim;

- można wskazać tylko trzy powiaty, w których zarejestrowano autobusy napędzane gazem. Są to: powiat strzelecko-drezdenecki, powiat zielonogórski oraz miasto Gorzów Wielkopolski. Z tych trzech powiatów znaczącą przewagę w liczbie takich pojazdów ma powiat zielonogórski, natomiast najmniej jest w powiecie strzelecko-drezdeneckim;

- największa ilość autobusów zasilanych alternatywnymi źródłami energii w latach 20152016 była w powiecie międzyrzeckim. Jednak w 2019 r. największą liczbę zarejestrowanych tego typu autobusów odnotowano w Zielonej Górze. Natomiast najmniejszą liczbę odnotowano w powiecie wschowskim;

- w województwie lubuskim również obowiązują założenia Białej Księgi Transport z 2011 r., które przewidują ograniczenie gazów cieplarnianych oraz zmniejszenie liczby pojazdów, które nie są zeroemisyjne do 2050 r.;

- władze jednostek terytorialnych województwa lubuskiego stosują się do Ustawy o elektromobilności i paliwach alternatywnych z 2018 r., inwestując w zakup zeroemisyjnych pojazdów transportu publicznego oraz dostosowanie infrastruktury do ich użytkowania. Świadczy o tym wzrost liczby takich środków transportu w perspektywie lat.

\subsubsection{Liczba samochodów osobowych w województwie lubuskim z podziałem na stosowany rodzaj napędu}

Poniżej zostaną przedstawione dane związane z rodzajem stosowanego napędu w samochodach osobowych w województwie lubuskim w latach 2015-2019 (rysunek 10). 


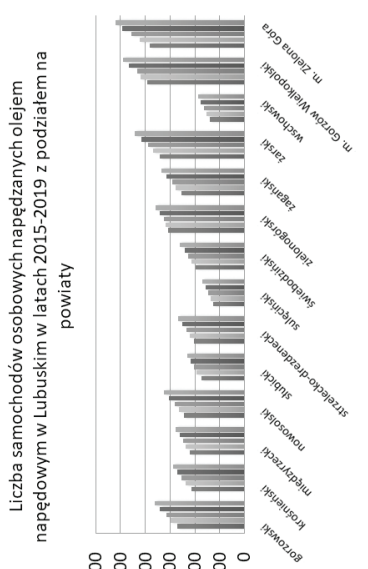

८ ८ : ८ : 8०

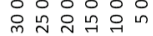

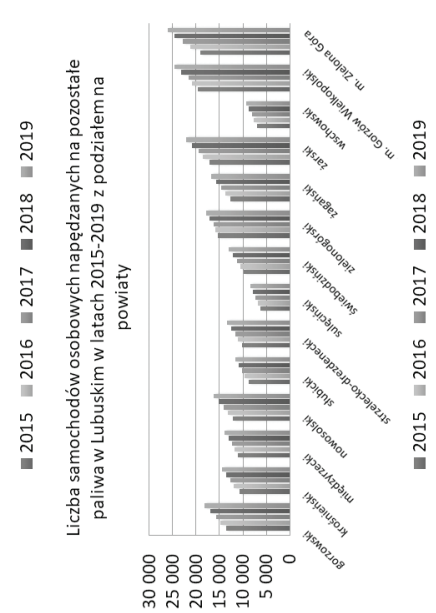

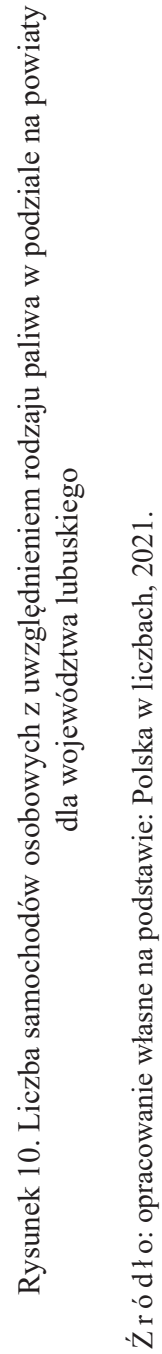
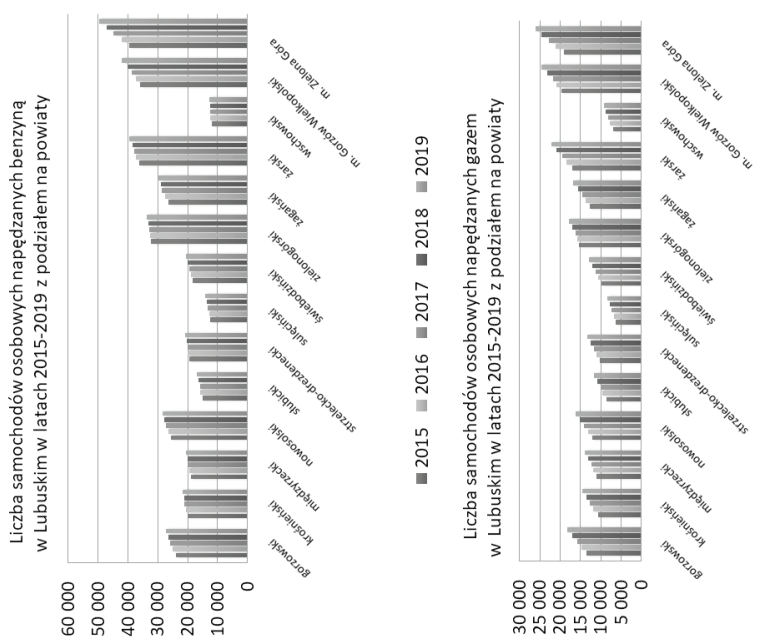

Z danych statystycznych o liczbie samochodów osobowych dla województwa lubuskiego (rysunek 10) wynika, iż:

- największą ilość zarejestrowanych samochodów napędzanych benzyną odnotowano w mieście Zielona Góra. W powiecie wschowskim występuje najmniej zarejestrowanych samochodów osobowych napędzanych benzyną;

- najwięcej samochodów osobowych napędzanych olejem napędowym zarejestrowano w Zielonej Górze. Najmniej takich pojazdów zarejestrowali mieszkańcy powiatów: sulęcińskiego oraz wschowskiego;

- największą liczbę zarejestrowanych samochodów osobowych o napędzie gazowym ma powiat żagański, natomiast najmniejszą - powiat słubicki; 
- największa ilość samochodów osobowych o napędzie alternatywnym odnotowano w: powiecie $\mathrm{m}$. Gorzów Wielkopolski oraz powiecie m. Zielona Góra. Z kolei najmniejszy udział zarejestrowanych samochodów osobowych o tym typie napędu przypada w powiecie sulęcińskim;

- Zielona Góra i Gorzów Wielkopolski to miasta województwa lubuskiego, które zostały objęte projektem stref czystego transportu w Polsce. W przypadku przekroczenia normy obecności dwutlenku azotu $\left(\mathrm{NO}_{2}\right)$ w powietrzu, miasta mogą wprowadzić takie strefy. Do takiej strefy mogą wjechać pojazdy: elektryczne, zasilane wodorem oraz CNG. Pojazdy z silnikami wysokoprężnymi i benzynowymi będą mogły wjeżdżać do stref po uiszczeniu odpowiedniej opłaty, pod warunkiem spełniania określonych kryteriów dotyczących norm emisji spalin;

- Zielona Góra, podobnie jak i inne miasta, wdraża usprawnienia wskazujące na stosowanie polityki proekologicznej w ramach koncepcji logistyki miejskiej. Zaliczyć do nich można: zwolnienie z opłat dla pojazdów elektrycznych i hybryd, liczne stacje ładowania aut elektrycznych itd.

Liczba aut osobowych z roku na rok wzrasta. Najbardziej preferowaną formą ich napędu są silniki elektryczne i hybrydowe, które w danych statystycznych mieszczą się w kategorii „pozostałe”. W tej kategorii nie ma jednak znacznego przyrostu liczby środków transportu ani prywatnego, ani publicznego.

\subsection{Wykorzystanie alternatywnych środków napędu - wnioski z badań}

Posiadacze samochodów osobowych oraz podmioty zarządzające miejskim transportem publicznym stoją przed nie lada wyzwaniem, aby sprostać dynamicznie zmieniającym się przepisom. Władze jednostek terytorialnych w Polsce, oprócz wprowadzania zmian w zakresie transportu publicznego, zachęcają dodatkowo mieszkańców do zrównoważonej mobilności, poprzez propagowanie zakupu samochodów osobowych zeroemisyjnych oraz korzystanie z alternatywnych środków transportu miejskiego, jak np. rower miejski czy hulajnogi. W odniesieniu do koncepcji logistyki miejskiej proponowane są następujące rozwiązania, które mogą oddziaływać na liczbę pojazdów z alternatywnymi formami napędu:

- rozbudowa sieci ładowania aut elektrycznych,

- rozbudowa infrastruktury dla aut elektrycznych i hybryd,

- minimalizowanie kosztów produkcji tego rodzaju pojazdów,

- dofinansowanie i finansowe preferencje dotyczące zakupu aut, parkingów, a także innych przywilejów dla posiadaczy aut elektrycznych i hybryd,

- lokowanie parkingów typu ,park\&ride” na obrzeżach miasta, z dogodnym dostępem do transportu publicznego oraz bez opłat parkingowych,

- stosowanie rozwiązań wpływających na poprawę ekologii w mieście takich, jak np.: park\&ride, bike\&ride, car-pooling, car-sharing itd.,

- rozbudowane sieci transportu publicznego na terenie miasta,

- inwestycje państwa i władz miasta w ekologiczne środki transportu publicznego,

- dofinansowanie do transportu miejskiego dla przemieszczających się po aglomeracji. 
Przedstawione propozycje nie wyczerpują wszystkich możliwości, ale są jednym z kierunków dalszego rozwoju. Przedstawiona analiza wskazuje, iż w analizowanym okresie liczba aut elektrycznych i hybryd, podobnie jak i autobusów wzrasta, ale w bardzo wolnym tempie. Rozwój ten z uwagi na rozwój technologiczny powinien być bardziej dynamiczny. Autorzy niniejszego artykułu mają świadomość, iż dane powinny być aktualniejsze, ale z uwagi na ich brak w międzynarodowych bazach, proponuje się w przyszłości pogłębić niniejszy temat.

\section{Podsumowanie}

Zmiany dokonujące się w gospodarce nie koniecznie mogą pozytywnie wpływać na społeczeństwo i środowisko. Główną ideą, jaka powinna przyświecać każdemu rozwojowi, powinno być zrównoważenie we wszystkich obszarach. W artykule podjęto tematykę zrównoważonego rozwoju w odniesieniu do transportu publicznego i prywatnego w myśl koncepcji logistyki miasta. Zrównoważony rozwój jest bardzo istotny i jest jednym z kierunków możliwości zaspokajania potrzeb przez przyszłe pokolenia. Jednym z rozwiązań w ramach logistyki miasta jest wprowadzenie środków transportu o ekologicznym wpływie na środowisko. Do takich środków zaliczono auta i autobusy napędzane elektrycznie oraz hybrydy. Jak widać z przeprowadzonych analiz statystycznych wykorzystanie ich jest na dość niskim poziomie. Większa ekspansja to w większości konieczność rozwoju infrastruktury dla tego typu pojazdów oraz niższe koszty produkcji, a co za tym idzie niższe koszty zakupu. Przyszłość dla tych form jest jednak bardzo optymistyczna, a co za tym idzie jeden z negatywnych czynników dla zrównoważonego rozwoju będzie mógł być z biegiem czasu wyeliminowany.

\section{Bibliografia}

Bajdor, P., Pawełoszek, I., Fidlerova, H. (2021). Analysis and Assessment of Sustainable Entrepreneurship Practices in Polish Small and Medium Enterprises. Sustainability, 13(7), 3595. DOI: https://doi. org/10.3390/ su13073595.

BZ. (2021). Wyniki badań bieżących. [online, dostęp: 2021-04-28]. Baza Demografii w Polsce. Dostępny w Internecie: https://demografia.stat.gov.pl/BazaDemografia/Tables.aspx.

Brent, A. C. (2021). Renewable Energy for Sustainable Development. Sustainability, 13(12). DOI: https:// doi.org/10.3390/su13126920.

Browne, E., Lindholm, M., Allen, J. (2015). Partnership among Stakeholders. W: E. Taniguchi, R. G. Thompson, City Logistics. Mapping The Future, Boca Raton: CRC Press.

Brzustewicz, P. (2013). Zrównoważone rozwiązania w transporcie miejskim - kierunki rozwoju. Acta Universitatis Nicolai Copernici. Zarzadzanie, 40, 85-96. DOI: 10.12775/AUNC_ZARZ.2013.007.

de Luca, M. (2010). City Logistics. TeMA-Journal of Land Use, Mobility and Environment, 3(2), 5-6.

Ehmke, J. F. (2012). Integration of Information and Optimization Models for Routing in City Logistics. New York: Springer. ISBN 978-1-4614-3627-0.

Fidlerová, H., Míkva, M. (2018). Application Of Selected Methods Of Industrial Engineering In Enterprises In The Context Of Sustainable Production. Quality Production Improvement, 2 (9), 71-91. DOI 10.30657/qpi.2018.09.04.

Gore, A. (1992). Earth in the balance. New York: Chelsea Green.

Gov.pl. (2021). Kolejny etap prac nad nowelizacją ustawy o zmianie ustawy o elektromobilności i paliwach alternatywnych [online, dostęp: 2021-05-21]. Dostępny w Internecie: https:/www.gov.pl/web/klimat/ kolejny-etap-prac-nad-nowelizacja-ustawy-o-zmianie-ustawy-o-elektromobilnosci-i-paliwach-alternaty wnych.

GUS. (2021). Bank Danych Lokalnych [online, dostęp: 2021-03-18]. Dostępny w Internecie: https://bdl.stat. gov.pl/BDL/dane/podgrup/tablica oraz https://spis.gov.pl. 
Huk, K. (2015). Logistyka miejska a społeczna odpowiedzialność biznesu - wspólne obszary zainteresowania. Zeszyty Naukowe Uniwersytetu Ekonomicznego w Katowicach ,Studia Ekonomiczne”, 249, 155-163.

Huk, K., Szudra, P. (2016). Aspekt środowiskowy w logistyce miejskiej w kontekście koncepcji społecznej odpowiedzialności biznesu. Przedsiębiorczość i Zarządzanie, 17(2) 147-156.

Huk, K., Witkowski, K., Wasilewski, W. (2016). Social aspects of urban logistics in the context of CSR. Logistics and Transport, 3, 13-20.

Japee, G. P., Oza, P. (2021). Redefining Sustainable Development. Psychology And Education, 58(2), 56205625. DOI: $10.17762 /$ pae.v58i2.2981.

Kelimeler, A. (2020). Constitution and Sustainable Development. İstanbul Hukuk Mecmuasl, 78(4), 19211957. DOI: $10.26650 /$ mecmua.2020.78.4.0007.

Norouzi, N., Ataei, E. (2021). Globalization and sustainable development. International Journal of Innovative Research in the Humanities, 1(2), 66-74.

Olajuyin, E. A, Areola, R. I. (2019). Energy and Sustainable development in developing countries. Journal of Electrical and Electronics Engineering (IOSR-JEEE), 14(4), 12-15. DOI: 10.9790/1676-1404011215.

Polska w liczbach. (2021). Województwo lubuskie w liczbach [online, dostęp: 2021-04-28). Dostępny w Internecie: https://www.polskawliczbach.pl/lubuskie.

Russo, F., Calabrò, T., Iiritano, G., Pellicanò, D. S., Petrungaro, G., Trecozzi, M. R. (2020). City Logistics Between International Vision and Local Knowledge to Sustainable Development: The Regional Role on Planning and on Public Engagement. Planning, 15(5), 619-629. DOI:10.18280/ijsdp.150504.

Sakhapov, R. L., Nikolaeva, R. V. (2021). Smart Transport Systems as a Method to Improve the Sustainability of City Transportation Network. In: IOP Conference Series: Earth and Environmental Science, 666(3), p. 032004. IOP Publishing.

Saniuk, S., Witkowski, K. (2011). Zadania infrastruktury transportu miejskiego w logistyce miejskiej. Logistyka, 2, 495-506.

Sekuła, A. (2002). Rozwój zrównoważony w skali gminy. W: A. Bałabana (red.). Europa bez granic - Polska a Unia Europejska (327-34). Gorzów Wielkopolski: Państwowa Wyższa Szkoła Zawodowa

Straka, M., Rosova, A., Malindzakova, M., Khouri, S., Culkova, K. (2018). Evaluating the Waste Incineration Process for Sustainable Development through Modelling, Logistics and Simulation. Polish Jurnal Environmental Studies, 27(6), 2739-2748. DOI: https://doi.org/10.15244/pjoes/81062.

Surówka, M., Popławski, M., Fidlerová, H. (2021). Technical Infrastructure as an Element of Sustainable Development of Rural Regions in Małopolskie Voivodeship in Poland and Trnava Region in Slovakia. Agriculture, 11(141).

Szymczak, M. (2008). Logistyka miejska. Poznań: Wydawnictwo Uniwersytetu Ekonomicznego w Poznaniu. ISBN 9788374173452.

Tadić, S., Zečević, S., Krstić, M. (2015). City Logistics-Status And Trends. International Journal for Traffic \& Transport Engineering, 5(3), 319-343. DOI: 10.7708/ijtte.2015.5(3).09.

Taniguchi, E. (2014). Concepts of city logistics for sustainable and liveable cities. Procedia-social and behavioral sciences, 151, 310-317. DOI: 10.1016/j.sbspro.2014.10.029.

Witkowski, K., Stajniak, M., Chojnacka, M. (2016). Zarządzanie infrastrukturą transportu drogowego w aspekcie rozwoju lokalnego na przykładzie województwa lubuskiego. Przedsiębiorstwo i zarządzanie, $17(12), 445-458$.

Ustawa z 11 stycznia 2018 r. o elektromobilności i paliwach alternatywnych, Dz.U. 2018 poz. 317.

WCED. (1987). Report of the World Commission on Environment and Development: Our Common Future [online, dostęp: 2021-07-15]. Oxford: World Commission on Environment and Development University. Dostępny w Internecie: https://sustainabledevelopment.un.org/content/documents/5987our-common-future.pdf .

Zarządzenie Komisji (UE) nr 459/2012 z dnia 29 maja 2012 r. Rozporządzenie (WE) nr 715/2007 Parlamentu Europejskiego i rozporządzenia (WE) nr 692/2008 ma znaczenie dla konsumentów związanych z usługami konsumenckimi (Euro 6). Dz.U. L 142 z 1.6.2012, s. 1. 16-24. 


\title{
Urban transport in the concept of city logistics and sustainable development
}

\begin{abstract}
Proper balance of all factors in the economy article deals with the topic of sustainable development is crucial for further development, as well as the future of society and living conditions. Hence, it seems important to properly manage the factors, as well as the exploitation of the environment. One of the solutions is responsible taking action in the field of city logistics. Only appropriate management in line with sustainable development can give the society good living conditions in the agglomeration, as well as further development of the economy through incoming investors. The in urban logistics in terms of the movement of people. The aim of the article is to present a level of the use of buses and passenger cars in agglomerations in terms of the means of propulsion (ecological and traditional forms of transport). The analysis was carried out by poviat. It was limited to Poland, with particular emphasis on the Lubuskie Voivodeship. The article was based on an analysis of the literature on the subject and on statistical data.
\end{abstract}

Keywords: concept of urban logistics, sustainable development, urban transport, buses 